\title{
Chapter 10: Taking Subsidiarity Seriously: What Role for the States?
}

\section{Brian Head}

\section{Introduction}

This chapter focuses on the issues and challenges for State governments in reforming Australian federalism. It proposes the more effective use of subsidiarity principles as a benchmark for assessing various reform proposals recently put forward from a range of perspectives. It examines some of the possible roles of state governments within an evolving federal system that has recently been characterised by a series of national agreements on major policy issues. The various proposals for fundamental redesign of the federation, including abolition of the States, are rejected. An argument is made in favour of a practical focus on effective and responsive governance, including a closer focus on more effective regional service delivery. This practical approach to 'good governance' would thus require continuing along the path of negotiating national agreements, taking subsidiarity more seriously, further clarifying roles in improved service delivery, and allowing greater flexibility and capacity for innovation at the sub-national levels. Having seriously embraced this path, more research needs to be done on the institutional arrangements that would most effectively sustain it in the long term.

As a prelude to analysing preferred solutions, we need to understand the nature of the problems with the Australian federal system as it has operated over recent decades. Concerns about the 'crisis of federalism' are raised in different ways by each generation (e.g. Greenwood 1946, Patience and Scott 1983). These are variously identified as problems with structures, problems with revenue-raising, problems with the allocation of powers, problems with coordination, problems with relational or political processes, problems with poor outcomes/performance in certain areas, or all of the above. The pressures for change come from many sources - some come indirectly through external and systemic pressures such as the global economy, and other sources of change are closer to home, such as political disputes over directions in important areas of policy. The federal system, at any given time, reflects its complex history. It offers a range of constraints, opportunities and incentives for the actors at three levels of government, and also for those major business and community groups that seek to influence policy arrangements. The variable identification of problems naturally gives rise to different prescriptions for change. 
It is important to understand that there are widely divergent views about what needs to be fixed in relation to the current three-tiered federal system. Among the many sources of criticism, it is useful to note five sectoral perspectives: local government, state government, the national government, business lobbies, and the larger non-government organisations (NGOs). The alleged deficiencies and preferred solutions are defined in different ways.

\section{Perspectives}

\section{Local government}

The local government sector sees itself as inherently closer to the people than the other levels of government. It also sees itself as deprived of the necessary powers and resources to undertake a full range of services (see Bell this volume). Local governments, being entirely dependent on state legislation, have a poor revenue base and have also been subjected to 'cost-shifting' (i.e. required to undertake tasks for which sufficient funding is not provided). In principle, this latter problem has now been recognised and addressed by an intergovernmental agreement (ALGA 2006). However, the ongoing reality may be a different story, and there are strong claims by local government leaders that the state governments are the oppressive and unnecessary layer in the current federal system. The Federal Government, for its part, has sometimes encouraged this viewpoint, by including local authority representation in inter-governmental forums, providing some funding programs directly to local government, and establishing various local and regional 'partnership' arrangements which minimise the role of the States.

\section{State governments}

For the eight states and territories, the problems of the federal system over the last forty years arise from three inter-related features of federal government power:

- fiscal centralisation (Head and Wanna 1990) - noting, however, that the massive redistribution of GST funds to the States since 2000 has greatly changed the political dynamics of this issue;

- overlap and duplication of federal and state powers in key policy areas, with increasing federal intrusion into traditional state areas of service delivery; and

- increasing centralisation of policy controls (regardless of the political party in office) through applying financial leverage (tied grants) and through expansion of the legal scope of federal powers through international treaties and High Court rulings (Court 1994).

Conservative defenders of a federal 'balance' (e.g. Gibbs 1993) are generally concerned about an increasing centralisation of power. Market-oriented defenders 
of federalism are also suspicious of centralisation and seek to encourage flexibility and competition among the constituent governments (e.g. Kasper 1993, Moore 1996). The solutions offered by state leaders (e.g. Goss 1994) have usually centred on reducing the incidence of tied grants, and seeking clearer demarcation between federal and state roles in key policy areas. Recent state leaders have recognised changing political and economic realities, by acknowledging that national economic efficiency requires a national approach (e.g. corporations law, competition law) rather than separate state regulatory frameworks; and even the recent movement towards a single industrial relations system is tacitly accepted.

\section{Commonwealth Government}

For the Commonwealth, the problems of the federal system over recent decades arise from the behaviour of the States, including:

- their capacity to delay or frustrate sound initiatives for improved performance standards, e.g. national standards for schooling;

- their failure to spend wisely on key services or economic infrastructure (Howard 2005, Abbott 2003, Abbott 2005); and

- their failure in some instances to support reforms to cut business costs by reducing regulatory inconsistencies and taxation on business transactions.

Federal politicians have a long history of supporting, in principle, the creation of a two-tier federal system without the current array of states (Hawke 1979, Macphee 1993), while acknowledging that this would be difficult to achieve. However, many commentators have noted that the diminution of state roles can proceed without constitutional change through the assertion of federal fiscal and legal powers (e.g. Craven 2005).

\section{Big business}

For large business organisations and associations, e.g. the Business Council of Australia (BCA), the federal system creates a higher regulatory burden and business imposts. The multiple layers of government produce unnecessary complexity, higher levels of taxation, a lack of uniformity or consistency in business regulations, complex project-approval processes, and higher compliance costs. Business lobbies - especially those representing larger firms operating across borders - are concerned to have uniform business regulations. They also want to ensure that economic issues affecting competitiveness (including the major areas of micro-economic reform, infrastructure and trade) are able to be addressed rapidly and decisively (Deveson 2006, Chaney 2006). During the debates of the early 1990s the BCA supported, in principle, a shift towards two-tier federalism (BCA 1991). However, the BCA has more recently supported 
national regulatory reform within a cooperative federal/state model with very strong leadership by central government (BCA 2006a, 2006b).

\section{Other major national interest groups}

For the other major national interest groups (e.g. NGOs concerned with family and community services, Indigenous issues, and the environment), there is often an impatience with fragmentation of responsibility for key outcomes and a preference for a national approach to major issues of program design. National approaches can be achieved either through federal imposition or through patient negotiation with the States; but the national NGOs often prefer centralised clarity over pluralist uncertainty. Calls for greater federal powers to over-ride the States on some social and environmental issues have been common over the years.

\section{Solutions: incremental or radical?}

These five critical perspectives define and locate the problems in different ways. Some place more emphasis on structural inequalities among the spheres of government, others focus on the inefficiencies of our complex system, and others on the lack of clear responsibilities for improving outcomes for citizens and business. While the diagnoses and prescriptions are diverse, there is a more fundamental distinction that can be drawn between those who support incremental models for change (adjust and improve current arrangements) and those who support radical models (fundamental reconstruction of governance systems including abolition of the current array of states).

The radical case for abolishing the States and building up the local or regional level of government has been proposed from two main viewpoints, which I will term the 'top-down rationalist' approach and the 'regional-responsiveness' approach. The top-down rationalist model for change is largely shared by both political centralists and the advocates of economic efficiency. Both argue for abolishing the States in order to cut wasteful duplication, cut costs of 'surplus' politicians and bureaucrats, and promote national standards. Massive benefits (up to $\$ 30$ billion annually) are suggested (Drummond 2001b), of which half arises from lower public sector running costs (simplified machinery of government), and half from boosting economic productivity (lower taxes and reduced regulatory costs for business). Former Brisbane Lord Mayor, Jim Soorley, claimed some years ago that the costs saved by abolishing the States (and thereby removing 'duplication, bureaucratic red tape and waste' between the three levels of government), could be used to eliminate Australia's foreign debt within 20 years (Soorley 1994).

As with most top-down models of change, proponents have given little consideration to the full range of issues. One problem is the lack of attention to likely costs as well as benefits - for example, the medium-term organisational costs of transitional arrangements, the difficulties of maintaining and building 
legitimacy and support while large-scale changes are underway, and the practicalities of leadership and change management where there are dispersed winners and losers. A second problem is the lack of attention to ensuring that the alleged deficiencies of states (fragmentation, inefficiency, appropriate powers, etc.) would not be repeated, and indeed on a much wider scale, among the new regional entities. It is very difficult to ensure that major changes do not create unintended dis-benefits.

A third set of problems is the lack of clarity about how many local/regional authorities are required to achieve the right balance between organisational capacity or effectiveness and democratic responsiveness - obviously somewhere between the current number of States/Territories (8) and the current number of local authorities (700). The answer has varied widely. Soorley (1994) claimed that 'about 20 ' new regional governments would suffice. On the other hand, a federal report on regional development identified 67 regions from the viewpoint of economic development characteristics (Kelty 1993), fewer than the 80 regions proposed much earlier by the Department of Urban and Regional Development (DURD 1973). Two Federal Labor MPs (Tanner and Snow) who proposed abolition of the States, in Federal parliamentary resolutions tabled in 1993-94, proposed to substitute 'less than 100' new local/regional bodies. Drummond (2000, 2001a) has more recently proposed 'between 40 and $60^{\prime}$ as the optimal number with a preference for the larger number; around 30 of these would be based on metropolitan and provincial cities.

An alternative to the top-down systemic approach is the regional responsiveness approach, which draws its strength from a sensitivity to regional identity, interests and sense of place (see Berwick this volume). Regional champions argue that 'communities of interest' are not sufficiently recognised in the current arrangements for state-level politics and administration. This sentiment underlies the 'New States' movements (discussed in Brown this volume) that have emerged in some areas of rural and remote Australia, especially in the larger States Queensland, New South Wales and Western Australia. Here, a distrust of metropolitan governments is closely linked with arguments that the historical boundaries of the large states are quite inappropriate. Support for greater devolution of powers to the regional level is stronger in such areas. This is a case-by-case approach, generated by local and regional sentiments and local leadership rather than by systems theory.

In terms of the ideal scale for coherent and effective regional entities, it might seem plausible to assume that some existing smaller jurisdictions such as Tasmania and the Australian Capital Territory are perhaps about the optimal size in terms of population and coherence. However, it is an open empirical question as to whether they are actually seen as more legitimate in eyes of their citizens than the larger jurisdictions. 
In terms of the appropriate powers required by regional entities, there is no agreement among the advocates of two-tier federalism about whether new regional governments should have the same powers as the existing States (and thus the same conflicts with the Federal Government over roles and responsibilities) or should become largely service delivery arms of the national government. There is a distinct possibility in two-tier federalism that centralisation could be even greater, with many of the more important state powers flowing to Federal Government and with regional governments being more fragmented and weaker than the current States.

\section{Subsidiarity revisited}

Lower levels of government usually favour the devolutionist principle of 'subsidiarity' - the concept that decisions should be taken as close as possible to the citizens by the lowest-level competent authority. Some established definitions of subsidiarity have already been supplied in this volume (see Brown, Podger this volume). As a principle, subsidiarity is widely invoked and supported, but in practice it is highly contested and could be used to justify a variety of practical outcomes in different circumstances. In principle, subsidiarity would entail that a central (or higher) level of government would perform only those essential tasks that (for reasons of scale, capacity or need for exclusive power) cannot be effectively undertaken at lower levels of administrative decision-making. In practice, subsidiarity has not supplanted power-politics in which the devolution of tasks is seen as a contractual arrangement between principal and agent.

In Australia, the principle of subsidiarity has attracted widespread support but without leading to long-term political and institutional changes. It has been invoked, firstly, by the States against the Federal Government; and secondly, but more recently, by local and regional entities against the State level. This sequence of acceptance is significant because, taking the second case first, the situation of local authorities can be quite parlous, with many being close to financial incapacity. The states have not seriously tried to devolve either revenue-raising powers or well-funded new functions to local government. Some cost-shifting has occurred and that has worsened the position of local authorities, even though, as already noted, such practices have recently been addressed by an intergovernmental agreement. The states have generally been content for local authorities to have a narrow role, and have not supported proposals for the recognition of local government in the Australian constitution. The states have taken some interest in regionalisation of their administrative arrangements for the delivery of services, but their links with local government remain problematic in most program areas.

However, the States have endorsed the principle of subsidiarity as a weapon in their ongoing arguments with the Federal Government aimed at reducing the 
States' financial dependency on the Commonwealth. This argument has been tightly interwoven with the long-running debate about how to reduce duplication and overlap of roles in the federation. Australia seems to have rejected traditional ideas about rational allocation of service functions to particular levels of government, since there are about ninety program areas in which the Commonwealth makes specific-purpose payments (SPPs) to other levels of government. Attempts to reduce duplication of roles during the Special Premiers Conferences of 1990-91 and in Council of Australian Governments (COAG) debates since 1992 have not led to clearer separation of roles. There is also no reduction in the political impetus, at federal level, for continuing expansion of SPP agreements.

While noting the lack of progress in implementing subsidiarity, it may be suggested that this principle could provide a useful benchmark for assessing, and for reforming, program design and funding arrangements. One approach, as recommended by the Victorian Government (ACG 2006), would entail the following elements:

- governments should focus on what really matters to the community - better outcomes, not bureaucratic arrangements between themselves;

- $\quad$ state governments should have the fullest scope for developing diverse ways to deliver improved services for their own communities and their own circumstances, within a broader national framework;

- SPP arrangements should be reformed in the mould of a partnership in which governments ensure that all of the related programs contributing to, say, health outcomes are well coordinated and complementary; and

- diversity in the ways that outcomes are achieved among the States is a fundamental driver of policy, program and service innovation - a key spur to improved effectiveness and efficiency (ACG 2006: 7).

This approach essentially attempts to marry a strategic partnership approach for setting objectives and for coordination - together with ensuring major opportunities for innovation, diversity and competition at lower levels of service delivery to reflect different circumstances.

This approach requires the Commonwealth to 'let go' some of its detailed controls. However, this remains difficult to achieve at the political level, where the incentives are for the Commonwealth decision-makers to retain all their power and control. The Commonwealth retains the key role in the design, funding and governance arrangements for future patterns of service delivery in many program areas. However, the Commonwealth has gradually abandoned the traditional administrative model of direct control of service delivery through a large federal workforce. In most policy fields, the Commonwealth now prefers to work through other providers and mechanisms (Head 2005). The pattern of recent decades has been to gain control through agreements, standards, and accountabilities 
leveraged by tied funding. There has been a strong trend towards greater use of contractual controls, linked to a variety of service providers:

- other levels of government (state, local, regional);

- private sector contractors; and

- community not-for-profit organisations.

Contract-based service delivery is not, however, a robust model for developing partnerships based on shared thinking and devolution of authority and resources.

\section{Regional approaches}

Both the Commonwealth and the States have been experimenting in recent decades with regional planning and program administration. The emergence of a new suite of policy initiatives that place more emphasis on devolution, is perhaps a sign that subsidiarity is finally being recognised as important and that without it, real change in services on the ground may be difficult to achieve. These now extend to everything from natural resource management (e.g. see Bellamy this volume), to transport infrastructure. Indeed, if regional policies and programs were well designed and based on local consultation, they might go part way to deflecting some of the hostile views held by the regions towards the metropolitan centres.

However, it is instructive that neither the Federal nor the State governments have been able to 'let go' in relation to empowering regional areas to develop their own agendas. In other words, subsidiarity remains problematic and largely rhetorical even in regional policy. For the States, regional administrative offices and special regional entities (e.g. catchment management authorities) are part of the State apparatus even though they are required to have close connections with local and regional interests. The role of local governments in these state-led arrangements varies widely around Australia. To the extent there is some devolution, it is not necessarily to the next (lower) level of government. For the Commonwealth, new regional bodies have been established as an alternative to state-sponsored bodies, e.g. in policy areas such as economic development and natural resource management.

The Federal Government in recent decades has claimed credit for serious work on some regional-scale planning and development activities. Examples include the mapping of 'regions' under the Whitlam government (DURD 1973), diverse plans and forums for regional economic development, regional forestry agreements in the 1990s, the Natural Heritage Trust regions developed since 1997, and various social policy programs aimed at 'place management' in and for disadvantaged communities. Yet in all these examples the Commonwealth model is generally contractual, retaining regulatory and funding power, while strongly promoting the involvement of non-state actors at local and regional levels. There is also a risk that both state and federal programs with a 'place' or 
locational emphasis are open to unfortunate political pressures such as pork-barrelling. Another problem is that so many regional programs have limited time-frames, exacerbated by being subject to short budget cycles, lack of bi-partisan support, or lack of genuine federal-state cooperation. Initiatives are thus vulnerable to changes in direction owing to political conflict or ministerial changes. The challenge is to develop program design principles that are durable, supported by communities, and institutionally robust.

The current half-hearted attempts at regional policy and programs need to be made more genuinely cooperative and involve real devolution if they are to achieve ownership at lower levels. This would require both the Commonwealth and the States taking subsidiarity more seriously, although within agreed national policy frameworks. It is likely that our current system lacks the political incentives necessary for this to occur. The system currently tends to respond to power and conflict rather than new strategic thinking. Conflict and tension is built into the federal system. Differences are not always a bad thing in a dynamic evolving system. Indeed, the negotiation of different viewpoints can sometimes be a useful catalyst for innovation and progress. In a rigid power-based system, however, the conflict becomes either a passive symbolic ritual or else becomes a polemical exercise in blame-shifting and confrontation (worse if complicated by party political differences). Under these conditions, conflict is not a creative force for developing better solutions.

The system thus needs specific machinery to encourage genuine negotiation and to facilitate innovation and excellence. Cooperative federalism, despite its legal and constitutional complexities (Saunders 2002), is the way forward on most large policy issues. The question becomes, how can efforts towards cooperative federalism - which tend to focus on relations between federal and state governments, and even then have a problematic history - be extended to pursue more genuine devolutionary models at the local and regional levels.

\section{Institutionalising cooperative federalism}

There is a strong case for a substantial Commonwealth role in strategic coordination (or 'steering') in key policy areas (Head 1989). Since the 1990s there have been some impressive results from 15 years of attempting to improve policy outcomes on national issues through federal/state agreements. Negotiation of national policy frameworks is an economical and effective way of achieving benefits without structural redesign of federalism. The Special Premiers Conferences and the Council of Australian Governments (COAG) forum have a solid record of achievement, as noted below. The political leadership of 'first Ministers' has been important for reform - the track-record of portfolio-based ministerial councils has been much less impressive. The availability of financial incentives from central government has also been an important tool in inducing support and achieving a number of national agreements. The States for their 
part have demonstrated their willingness to cooperate to resolve interstate anomalies and inefficiencies, and to cooperate with the Commonwealth in achieving important national goals in the public interest. Each level of government has made considerable progress with the efficiency and effectiveness agendas inside their own jurisdictions.

Some national problems have been so large that cooperative solutions among the governments have been seen as essential. This was recognised in 1990 with a new decision-making forum for Heads of Government, the Special Premiers' Conferences, to deal with overarching issues such as microeconomic reform, principles of environmental management, government roles in service delivery, and the efficiency of regulatory regimes. This was renamed the Council of Australian Governments in 1992. For those who doubt whether a cooperative approach can produce results, the achievements of the 'golden' period 1990-95 were considerable (Head 1994; Painter 1998):

- national framework legislation for non-bank financial institutions;

- mutual recognition of interstate standards for goods and occupational qualifications;

- standardised data on the comparative efficiency of government business enterprises;

- establishment of National Rail Corporation to manage interstate rail freight;

- establishment of Australian National Training Authority to coordinate vocational training;

- establishment of National Grid Management Council to coordinate electricity supply and distribution protocols;

- agreement on uniform road transport regulations;

- establishment of National Food Authority to coordinate food standards;

- agreement on national approach for distribution and pricing in the gas and water industries;

- agreement on balanced approach to ecologically sustainable development and a national approach to greenhouse issues;

- inter-governmental Agreement on the Environment (IGAE) to establish a consultative approach on relevant national issues and agreement to establish a National Environmental Protection Council to determine quality standards for air, soil and water;

- agreement on strategies for disability services;

- rationalisation of structure and operation of ministerial councils;

- agreement on a national approach to teaching Asian languages and cultures in our school curriculum;

- principles for National Competition Policy following from the Hilmer Report;

- a national approach to reform of legal services and the legal profession; and 
- national approach to performance indicators for benchmarking the provision of government services were considerable.

State leaders have insisted that if the federal system is run as a centralised hierarchy, there is little incentive for innovation and cooperative problem-solving. If the system is run as a team event, albeit with a special role for the central government, it is likely that better results will be produced. The states remain responsible for very substantial issues of service delivery and business efficiency. In some cases, it is appropriate that the States should compete for citizen support by offering attractive packages of social and economic policies, tailored to regional needs and preferences. Cooperative federalism can be successful with a degree of goodwill, even where the 'first Ministers' include leaders of different political parties. Difficulties remain in seeking to determine what system of government will best facilitate joint problem-solving for genuinely national challenges and encouraging innovation and diversity at each level of government while tackling the major issues of service quality and economic productivity. The Business Council (BCA 2006b) has argued that progress should not depend on the 'accident' of whether political leaders have sufficient goodwill to engage in constructive debate and reform. The BCA proposes a strengthening of national strategic capacity by establishing a Federal Commission to identify key issues requiring a collective response, and to report on progress in implementing previous COAG agreements. Despite the manifest failure of previous exercises to reduce duplication and overlap, the BCA also proposes a Federal Convention to examine re-assignment of roles and responsibilities on key policy arenas and to achieve a more uniform approach to national markets.

The States have been increasingly willing to enter into national agreements on many policy areas concerning the economy and cross-border issues: e.g. corporate business regulation, competition policy, trading enterprises, mutual recognition, energy, water, transport, environment, and benchmarking of service delivery. The States, it must be said, should continue to lift their game at a strategic level, as is being attempted through the second wave of productivity reforms and human capital reforms being considered by COAG with strong input from Victoria (Glover 2006; Wilkins 2006). For the States, the political necessity of developing a more coherent 'collective' position to balance the power of the Federal Government, has led (after many false dawns) to the establishment of a states-only forum, the Council for the Australian Federation, in mid-2006. Its key role, apart from information-sharing, is to discuss strategic issues without the presence of the Commonwealth. If it can focus on strategic long-term issues (e.g. the COAG productivity agenda) rather than tactical skirmishes with the Commonwealth, it may prove to be useful. 
Intergovernmental agreements supported by tied grant programs have often been too rigid and overly focused on detailed operational controls. Agreements have often failed to reflect a genuinely cooperative national approach to policy development, let alone facilitate state or regional differences in policy settings. The States have argued for many years that the federation would be better managed if the following occurred:

- National strategic objectives should be cooperatively negotiated with the States in policy areas genuinely requiring a national approach. COAG should be the ongoing forum for debate and decision on major strategic issues including regional policy frameworks;

- However, except in Commonwealth-only service areas, program implementation should be essentially a matter for the States and regions, with financial accountability lying primarily through State Parliaments and State Auditors-General;

- National agreements should increasingly focus on the goals and outcomes expected by governments, with less emphasis on detailing quantitative inputs. The availability of consistent and reliable performance information on the major areas of service delivery in the last decade has reinforced the strength of this position. However, it remains an educational challenge to convince the media, interest groups and federal politicians that an outcomes focus, anchored in published comparative performance information, is really a superior form of accountability;

- Review the role of 'tied grants' in jointly-funded government programs. Commonwealth SPPs, which might be a minority of total program funds, are used as leverage to influence the goals and components of the whole program area. A significant proportion of tied grants could be converted into either block-funding for the agreed policy purpose (e.g. school education) or converted into general revenue grants, providing that agreed goals and performance measures are in place; and

- Progress should be made in redefining the spheres of policy and service responsibility for each level of government. While there can never be precision in dividing roles in our federation, there has been insufficient effort to assign certain functions more clearly to one level of government (e.g. universities to the Commonwealth). Canberra has found it difficult to agree that school and vocational education should largely be a matter for the States, subject to broad national agreement on coordination, equity, and performance indicators. Healthcare, the other large-spending area of overlapping federal/state roles, remains a political and administrative minefield (see Podger this volume). The Commonwealth has recently backed away from radical plans for structural reform in favour of 'incremental reforms' (Abbott 2006). 


\section{Conclusions}

It is true that, if the Australian people were confronted with a 'greenfields' choice between alternative paper plans for good government, they might choose a more simplified structure than the current complex three-tier model. The attitudinal research set out by Gray and Brown (this volume) certainly tends this way. However, the two-tier option, despite its apparent simplicity and rationality, is ultimately impractical for the foreseeable future. The business case for moving rapidly towards two-tier federalism, with the current array of states displaced or absorbed in various ways, remains rhetorical and impractical; especially the radical version of constitutional change to abolish the States. It is therefore more productive to apply our imagination and political goodwill towards addressing the apparently high level of public interest in federalism reform, by making our system work a lot better.

This should not be seen as a defence of archaic 'States' rights', a rhetoric whose time has truly passed. Rather, this is an opportunity for existing state jurisdictions to recognise they can play an important role in purposeful reform of policy and administrative arrangements - even if this means being prepared to share power with local and regional bodies in more serious and durable ways than previously achieved, or indeed previously tried.

Instead of their historical preoccupation with resisting the Commonwealth, the state governments should focus their attention on program areas that deserve to be organised at a state level (i.e. on the spatial scale between national and local). They should divest themselves of matters that can better be handled federally, regionally or locally. Areas that are directly concerned with national economic regulation should be ceded to the federal level. Some matters that the States largely control should be devolved, with appropriate authority and funding, to lower levels for planning and action. Matters for such consideration might include urban and regional development, and improved service integration for residents of provincial and rural areas. The state level could assist by ensuring good governance, equitable treatment of local areas, and support to address skills shortages.

Insofar as structural changes to improve the federation deserve further consideration, more research and policy development is needed on options, transitional arrangements, and the testing of public support for various objectives and institutional options. In the meantime, three-tier federalism should be improved by innovative attempts to deliver better services through a combination of national agreements, clear responsibilities for service arrangements, and a more robust approach to regional-level policy and programs that involves genuine devolution. This would require both the Commonwealth and the States taking subsidiarity more seriously, within agreed national policy frameworks. The States need to take this opportunity to rethink their core business (what works 
best at state level?) and support both sensible devolution and national frameworks. Half-hearted attempts at regional policy and programs (by both the Federal Government and the States) need to be made more genuinely cooperative, and involve genuine devolution.

\section{References}

Abbott, Hon T. 2003, 'Responsible Federalism', Norman Cowper Oration, Sydney, June; see also 'Responsible Federalism' in W. Hudson and A. J. Brown (eds) 2004, Restructuring Australia: Regionalism, Republicanism and Reform of the Nation-State, Federation Press, Sydney.

2005, 'A Conservative Case for Centralism', The Conservative, No.1, pp.45.

2006, Ministerial address to conference on Making the Boom Pay, cited in The Australian, 3 November.

Allen Consulting Group (ACG) 2006, Governments Working Together? Assessing Specific Purpose Payment Arrangements. Report to the Victorian Government, ACG, Melbourne.

The Australian, editorial 5 June 2006, 'Profligate Premiers'.

, editorial 14 July 2006, 'Federalism a Test of Leadership'. , editorial 30 October 2006, 'Less Talk, More Action'.

Australian Local Government Association (ALGA) 2006, 'IGA on Cost-Shifting: historic agreement to ease cost shifting burden on councils', media release, Canberra, 12 April.

Business Council of Australia 1991, Government in Australia in the 1990s, BCA, Melbourne.

2006a, Modernising the Australian Federation: A Discussion Paper, BCA, Melbourne.

2006b, Reshaping Australia's Federation: A New Contract for FederalState Relations, BCA, Melbourne.

Chaney, M. 2006, 'Make a Federal Case of it', The Australian, 10 July.

Court, R, 1994, Rebuilding the Federation: an audit and history of State powers and responsibilities usurped by the Commonwealth in the years since Federation, WA Government, Perth.

Craven, G. 2005, 'Federalism and the States of Reality', Policy 21 (2), pp.3-9. 2006, 'Business gets its Absolutes out of Order', The Australian, 17 October. 
Department of Urban and Regional Development (DURD) 1973, Regions, AGPS, Canberra.

Deveson, I. 2006, 'One Step from Best in World', The Australian, 14 July.

Drummond, M. 2000, 'Regional government can transform Australia', Online Opinion 15 July. www.onlineopinion.com.au

2001a, 'Towards a best-possible new system of government', Online Opinion, 15 January. www.onlineopinion.com.au

2001 b, 'A $\$ 30$ billion annual boost that better government can deliver', Online Opinion 31 January. www.onlineopinion.com.au

Gibbs, Sir H. 1993, 'The Threat to Federalism', in Samuel Griffith Society, Upholding the Australian Constitution Vol 2: Proceedings of the Second Conference of the Samuel Griffith Society, Samuel Griffith Society, Melbourne, pp.183-193.

Glover, R. 2006, 'Collaborative Federalism: Getting More from the Competition of Ideas', Public Administration Today, No.7, pp.4-7.

Goss, W. 1994, 'Reinventing the States', paper to the 2020 Vision Forum, Brisbane.

Greenwood, G. 1946, The Future of Australian Federalism, Melbourne University Press, Melbourne.

Hawke, R.J. 1979, The Resolution of Conflict, ABC Boyer Lectures, Sydney.

Head, B.W. 1989, 'Federalism, the States and Economic Policy', in B. Galligan (ed.), Australian Federalism,Longman Cheshire Melbourne, pp.239-259.

1994, 'The Federal Imagination: Making the System Work Better', paper for University of Melbourne conference on Australian Federalism, July.

1999, 'The Changing Role of the Public Service: Improving Service Delivery', Canberra Bulletin of Public Administration, No.94, pp.1-3.

2005, 'Governance', in P. Saunders and J. Walter (eds), Ideas and Influence: Social Science and Public Policy in Australia, UNSW Press, Sydney, pp.44-63.

Head, B.W. and J. Wanna, 1990, 'Fiscal Federalism', in J. Forster et al (eds), Budgetary Management and Control, Macmillan, Melbourne, pp.22-40.

Howard, Hon J.W. 2005, 'Reflections on Australian Federalism', address to Menzies Research Centre, Melbourne, April.

Kasper, W. 1993, ;Making Federalism Flourish;, in Samuel Griffith Society, Upholding the Australian Constitution Vol 2: Proceedings of the Second Conference of the Samuel Griffith Society, Samuel Griffith Society, Melbou, pp.167-181. 
Federalism and Regionalism in Australia

Kelty, B. 1993, Regional Development: report of the taskforce, Department of Industry etc., Canberra.

Lewis, D. 2005, 'Altered States', Sydney Morning Herald, 25 January.

Macphee. I. 1993, Address to the Samuel Griffith Centenary Seminar, Brisbane.

Moore, D. 1996, 'Duplication and Overlap: An Exercise in Federal Power', in Samuel Griffith Society, Upholding the Australian Constitution Vol 6: Proceedings of the Sixth Conference of the Samuel Griffith Society, Samuel Griffith Society, Melbourne, pp.37-64.

Painter, M. 1998, Collaborative Federalism: Economic Reform in Australia in the 1990s, Cambridge University Press, Melbourne.

Patience, A. and J. Scott (eds) 1983, Australian Federalism: Future Tense, Oxford University Press, Melbourne.

Saunders, C. 2002, 'Collaborative Federalism', Australian Journal of Public Administration, 61 (2), pp.69-77.

Soorley, J 1994, Address to the Centenary of Federation Advisory Committee, May.

Steketee, M. 2006a, 'Unwanted, but State Governments are here to stay', The Australian, 27 April. 2006b, 'A Federal State of Recalcitrance', The Australian, 24 June.

Wilkins, R.B. 2004, 'Federalism: Distance and Devolution', Australian Journal of Politics and History, 50 (1), pp.95-101.

2006, 'A New Era in Commonwealth-State Relations?' Public Administration Today, No.7, pp.8-13. 